\title{
CutBank
}

Volume 1

Issue 69 CutBank 69

Article 6

Summer 2008

\section{Millions Now Living Will Never Die}

Matthew Clark

Follow this and additional works at: https://scholarworks.umt.edu/cutbank

Part of the Creative Writing Commons

Let us know how access to this document benefits you.

\section{Recommended Citation}

Clark, Matthew (2008) "Millions Now Living Will Never Die," CutBank: Vol. 1 : Iss. 69 , Article 6.

Available at: https://scholarworks.umt.edu/cutbank/vol1/iss69/6

This Prose is brought to you for free and open access by ScholarWorks at University of Montana. It has been accepted for inclusion in CutBank by an authorized editor of ScholarWorks at University of Montana. For more information, please contact scholarworks@mso.umt.edu. 


\section{MATTHEW CLARK}

\section{Millions Now Living Will Never Die}

Finalist, 2008 Montana Prize in Creative Nonfiction

The Kingdom Hall's machine answers when I call, announcing service times and promising to call back. My phone rings the next day. North of Iowa City, over Interstate 80, I curve and roll down Northgate Drive, past the sod-covered lawns fronting businesses that specialize in repair: Clinic of Electrology and Laser, Orthopedic Clinic, Oral Surgery Associates, Iowa Foot and Ankle, Urologic Associates. In the deserted Jehovah's Witness parking lot, curbed islands of birches flutter like palms. The sound of traffic speeds through ubiquitous fields of unharvested corn. Advertising to the highway, a billboard exposes only its skeletal supports to me. I duck my head to the wind and walk the pavement. Over the entrance of the Kingdom Hall hunching at the back of the lot, a concrete awning suggests valet hospitality.

I see him, the Elder I spoke with over the phone, sitting in a room at the rear of the sanctuary. He stands to introduce himself and encourages me to shorten his name.

"Matthew," I say. "Not Matt."

Of course, he says. He'd love to help me understand the truth about Witnesses.

The table between us, set like a dentist's tray neatly with literature, is too small for our large frames. Whenever I lean forward, he leans back. Whenever I lean back, he leans forward. He shows me one of the texts, a colorful evangelizing handbook, leather bound and titled, Benefit From Theocratic Ministry School Education. For Jehovah's Witnesses, there is no dichotomy between lay worshippers and a spiritual class. Every member is a minister. I open the burgundy cover to a table of contents referencing 53 Studies. Study 1 covers Accurate Reading. Study 2 promotes Words Clearly Spoken. Studies 8, 9, 10, 11: Suitable Volume, Modulation, Enthusiasm, Warm and Feeling. Study 50 teaches An Effort To Reach the Heart. It teaches Naturalness. It teaches to Rely on Jehovah. Honor Jehovah. Know How You Ought to Answer.

Don't quote me, he grins, his Words Clearly Spoken. It would be best if he remained nameless because, he says, Witnesses do not self-promote. It isn't 
important, he'd say, that his small teeth are like kernels of corn on the cob, that his hair is thin and white and parted, that his thick eyebrows arch when he inspects his bifocals, that he stands tall and straight, that his pleated dress pants billow, that his blue dress shirt reveals tan forearms. He doesn't want to inject himself into this, he says.

What I know about the globe's 6.5 million Witnesses, I've plucked from the grapevine: You mean, Jehovah's Wickedness? Whenever we saw them coming, my mom told us to pull the shades and lock the doors and turn off the TV. They made her quit her job and abandon her friends. They're spooky, confused, wrong, not right, desperate, gullible, lost, nuts, crazy, creepy.

Apostates, he shrugs. People, he says, fear what they don't understand.

He offers me the SPECIAL November 2007 issue of Awake! magazine. It is the familiar size of a blue university test booklet. On the cover, a trim young man white, wedding band, watch studies in warm library light above the title, Can You Trust the Bible? I flip through and find Shakespeare quoted alongside King Solomon. "Trust not," it reads, "to rotten planks."

On average, 28 million Watchtower magazines, the better known twin of Awake!, arrive biweekly at Kingdom Halls worldwide. Begun in 1879 as Zion's Watch Tower and Herald of Christ's Presence, it has been published continuously ever since, distributed gratis on street corners, slipped under doors and shared with those who, out of whatever sympathy, frustration, or curiosity, accept them. Now, The Watchtower has become a household name, reaching an audience nine times larger than Newsweek, Sports Illustrated, or Playboy. Despite the apocalyptic illustrations of venomous skeptics in sandals, babies bloated with starvation and imminent orbiting missiles, articles maintain an essentially optimistic message: Tou can endure!

All of the literature, he says, is available on the website free of charge.

There are fourteen titles on the website. The Bible, bible study aids, brochures, and magazines are all composed in obsessively accessible prose, rife with rhetorical questions, summary headings, and dated colloquialisms. Witnesses also publish Braille materials for the blind and sign language videos for the deaf. Multilanguage Electronic Phototypesetting System software, developed by Witnesses, translates the literature into over 432 languages. Other mainstream publications, like The Atlantic or Nature or The New Yorker, are cited for corroboration. There are personal stories. There are study questions to aid retention. The purpose of the literature, professedly an altruistic one, is salvation.

He invites me to come to the Public Meeting and Watchtower Study on 
Sunday, smiling broadly, opening his arms. He knows I'll like it there. There'll be families and folks my age. There won't be a collection plate or anything, he says. It'll be just like school. I don't have to wear anything special. He'll save a seat, he says, in the back with him and his wife. There's nothing to be afraid of.

Low ceiling fans circulate the air-conditioned air inside the Kingdom Hall. Blinds shade three South-facing windows. I sit with him and his wife. Though I've told him I only want to observe, he's treating me as an honored guest. He gets me this week's Watchtower, the Bible and a hymnbook from the bookcase in the back. Keep them, he says. He fetches a footstool for his wife. There are four other assemblies during the week and, like the Sunday Meetings, they all follow a strict procedure. We voice a subdued hymn, no single voice distinct from the unison. After bowing our heads in prayer, we sit. Over half the 150 heavy cushioned chairs are full. Iowa City is not this diverse. Accents, postures, and colors, surprise me. Here, men's haircuts are almost military, parts shine with gel, bald patches gleam, tight Afros fizz. There are braids, highlights, weaves, bobs, hair-sprayed bangs. There are pearls and there is mascara. This is Sunday best. Women wear dresses. Girls wear dresses. Boys wear suits. Children color with crayons. They bounce and whisper and crawl across laps. Men wear suits. Beside every Brother's chair, in brown leather or black leather, with brass buckles or solid flaps or Velcro or snaps, leans a briefcase.

An Elder from a neighboring congregation, maybe Muscatine, maybe Moline, or the Quad Cities, or Kansas City or Silvis, delivers the Public Talk from an unremarkable podium. Gesticulating with subtle precision, as if he were holding something delicate between thumb and fingers, the Elder speaks with an emotion that feels rehearsed, forced, psychiatric. He invites us to consider his talk with an open mind. He is middle-aged or young, slim or bellied, bent or upright. An Elder is always a man. As written in 1 Timothy 3:1-6, he is "irreprehensible, a husband to one wife, moderate in habits, sound in mind, orderly, hospitable, qualified to teach, not a drunken brawler, not a smiter." Above all, he must be, the Bible says, reasonable.

The Elders who speak have all been trained to deliver talks in a consistent manner at the Witness's sparkling complex in Patterson, New York. There are 160 Public Talks approved and outlined by the organization, though each speaker is free to flourish:

Small rudders steer tremendous boats.

Love is like a muscle. 
Human speech is unquestionably a marvel!

Everyone highlights passages and everyone jots in notebooks and everyone follows along and so do I. Study 35: Repetition for Emphasis, comes to mind. Isn't that a nice example? 1 Chronicles 29:9 is such a nice passage. Now isn't that a nice comment? What a nice chance to help someone.

One week, we learn that Money Cannot Buy True Friendship.

Another time, the lecture teaches How to Keep a Clean Conscience in a Sinning World.

We hear about Showing Respect and Love in One's Marriage. Forget Barnes and Noble and all those self-help books, one speaker says, Jehovah wrote the authoritative marital guidebook. True Christians, we are told, sometimes must sever ties to nationality, culture, friends and family. As Jehovah's Witnesses, it is comforting to know our six and a half million siblings are the best family we could ever have. On this point the speaker is emphatic: we all belong to Jehovah. Our Christian identity, he continues, is so valuable that Satan and his Demons are constantly trying to steal it. Would you not agree that identity theft is common in the world?

A herd of puffed parkas, scarves, hats, hoodies, mittens and ear-muffs wait for the walk-signal to cross. The wind blusters even the shadows. Men armed with bags from the pet supply store hustle past in an effort to stockpile cat litter. I've got a window seat at the coffee shop where we've arranged to meet. He's late.

The Witnesses are used to waiting. Theirs is a history of delayed prophecies. The world keeps surprising them. It spun right past 1878, the date set for a pre-apocalyptic reunion in heaven with God. Then 1881 passed without the expected ascension. Biblical chronology indicated the End in 1914 and WWI seemed to concur. A mistake, they said, 1915 for sure. Then the sun rose and it was 1920 and they speculated: 1925? 1975? Today, the literature terminates the wicked system of things at an unspecified, but imminent tomorrow.

Students sip bubble tea from straws.

A Pumpkin Latte, please. Make it a double tall mocha. Soy thanks, not skim.

He calls to say he's on his way, he says, if I'll wait just a little longer.

"Sure," I say. It's not like it's the end of the world.

He arrives wearing a dark suit and a sky blue shirt and apologizes again. It's cold out there, he says, he'll have a hot chocolate. He asks about my parents, my friends, my hometown. Milk-foam coats his upper lip. He tells me a bit 
about his former congregation: twenty-three members, Tipton. The contours of that farm country, he says, are as familiar as bible verse. He and his wife have just moved closer to town, he says, because she doesn't like winter driving.

"Of course," I say. "A little ice can send you spinning."

The conversation skids and slips from weather to baseball to paradise.

We do not want to die, he says, earnest and open. But, he says, we do look forward to everlasting life. Would the Creator limit our ability to learn and improve to a life span of just seventy or eighty years? From the earliest times, he reminds me with ever-present doubt-silencing conviction, mankind has dreamed of living forever. We see that Jehovah put the notion of everlasting life in our head in Ecclesiastes 3:11. Now why would Jehovah do that, he asks, if He didn't want us to enjoy everlasting life?

For Witnesses, the everlasting is not a figurative infinity, or a self-annihilating nirvana, or a personal heaven. Witnesses do not believe in hell or an eternal soul. Paradise is literally here, on this Earth, repopulated with the people who have lived before. Jehovah, he continues, encourages us to picture ourselves on the coming Earthly paradise. He pictures it often. He can't really tell me exactly in five minutes, he says, but that's it in a nutshell. Witnesses, he says, do not self-promote. Let's look in Isaiah or Revelations. He opens the Bible to address the points of my metaphysical confusion. No, he says, boredom will not be an issue. Natural disaster and aging and sickness and sorrow will cease. Relatives, he says, will be reunited. We will get older, he says, and then younger together. It will be just like life now. Only, he says. The creased skin, the hubbub, the promotions billboarding the mall across the street, the pamphlets clogging sewer grates, the dim autumn light, they will all disappear.

He removes his glasses and I am touched by all I see in his eyes: longing, fatigue, years.

Only, he says, it will be perfect.

Following the Public Lecture at the Kingdom Hall and concluding hymn \#161, ninety-thousand congregations across the globe will turn to page sixteen of The Watchtower for today's Study. Ninety percent of all congregations study the same article every week. Millions of briefcases open. Millions of magazines turn to dog-eared pages, highlighted passages, underlined phrases.

At the front of the Hall, a Brother reads into a microphone from this week's Watchtower. Another Brother poses the corresponding questions that footnote the bottom of each page. Two young Brothers patrol the aisles with microphones so the Witnesses can be heard. Millions of hands go up. Tens of mil- 
lions of fingers: brown fingers, pale fingers, smooth, wrinkled, ringed fingers, manicured fingers, missing fingers. Yes, Brother - Yes, Sister-

The Witnesses publish four bullet points instructing HOW TO COMMENT AT MEETINGS. The fourth bullet suggests that each Witness try to comment in his or her own words. The answers come straight from the text. They come straight from personal experience. They repeat. They ramble. They make no sense. They are common sense. There are more hands than we have time for. Millions of answers are one answer:

Everyone's going to lose their life, and that's the Truth.

When we put all these things together the Truth makes a lot of sense.

The Truth makes good sense because it comes straight from Jehovah.

The blond boy in front of me can't be older than nine. His mother pulls him close with an arm around the over-sized shoulder of his sandy-hued suit coat. He leans into her chest to read from the Watchtower on her lap. That's where his notes are. He starts to read, but the microphone isn't on. With remarkable composure, he waits. Because, he says both shy and sure, his small voice amplified when the mic clicks on. Because Jehovah loves us, that is why we follow His Truth.

The young Brother looks to his mom with big eyes.

Yes, she squeezes him to her. Good job.

Paragraph four. The next question has two parts. Yes. Thank you, the Brother leading the question session nods. Paragraph five. Six million hands, one answer. Thank you. Six, question, hands, answer, thank you. Seven. Eight. Nine.

At a later date, the coffee shop is crowded with University students in University sweats. The man in a light hounds' tooth suit and matching vest attracts admiring gazes. Before sitting, he asks me about what it is I'm writing again.

"We all want answers," I tell him slowly. "And reasons, and reassurance." We are, after all, rational animals, I continue, speaking generally. We want to know things for sure. We are perpetually asking and seeking and notknowing and believing. I can see that he, this calm, content, sagely gentleman, possesses something tremendous. He has found something so powerful in the answers he knows by heart, that he seeks no more reasons, needs no more reassurance. If true salvation is possible, if salvation really exists, whatever salvation is, then, I reason, his salvation must certainly be the genuine item.

He sits, cautiously satisfied. He has maybe ten suits he tells me, though 
he doesn't really know. Maybe, he says, it's closer to five or six. Remember, he says, Witnesses do not self-promote. Last week, when he saw me noting his hometown, he stopped me. It would be best if I didn't write that down, he said. Today, at this familiar table, I've assembled a coffee cup and water bottle barrier, but it just makes his scrutiny more conspicuous and his insistence on personal transparency more contradictory. It's not that he isn't interested in me, he qualifies, or that he doesn't want us to become acquainted. By way of explanation, he hands me a brochure titled Jehovah's Witnesses, Who Are They?

The brochure, like all the literature, credits no authors, though Jehovah's Divine inspiration is suggested. Whereas the emperor was exposed by his invisible clothes, the Witness is invisible by his Watch Tower guise. There are no portraits on the walls at the Kingdom Hall. We do not idolatrize, he says. He doesn't know the names of any of the current members of the Governing Body. A little research reveals that when it was created in 1971 it contained eleven members: Frederick Franz, Raymond Franz, George Gangas, Leo Greenlees, John Groh, Milton Henschel, William Jackson, Nathan Knorr, Grant Suiter, Lyman Swingle, and Thomas Sullivan. The Governing Body has never consisted of more than eighteen men, selected for their loyalty rather than for their educational or their spiritual achievement. The majority are septuagenarians. Raised on and never weaned from the organization they refer to as their mother, the Governing Body governs from behind closed doors at the World Headquarters in Brooklyn, New York.

Every one of the Governing Body is one of the 8,000 living Anointed Ones. The Anointed Ones belong to the 144,000 Faithful and Discreet Slaves who will sit on cumulus thrones beside Him in his Heavenly Kingdom after Armageddon. Throughout history, the future rulers of paradise have known in their hearts of hearts that Jehovah has anointed them.

It isn't important, he says, that he's met one or two Anointed Ones. They are just like you and me. It isn't like they have wings or a halo or are trailed by lightning or anything. Abel was the first, he says. Noah and his three sons were also and so was Jesus.

In the BX 8526s of the University Library stacks, there are over four shelves of literature pertaining to Jehovah's Witnesses. Last week over coffee, the Witness suggested I check the website for information about Charles Taze Russell, the founder of the modern movement. The website yielded nothing substantial. Here, in the stacks, whole chapters are devoted to him along with all seven volumes of his magnum opus, Studies in the Scriptures. In one book, I see a glossy 
picture of him taken in 1879. He is just a year older than $\mathrm{I}$ am, and rich. A stripe of beard connects his lip to his chin and then the trim facial hair follows up his jaw to his ear where it meets thick dark hair, combed so stiffly he might just have emerged from a bath. His wide eyes and his coy lips taunt me with their lack of dimension.

I turn each page hoping for a more intimate knowledge of this man, hoping to know the truth about him. Years pass as I skim. He is born in Alleghany, Pennsylvania in 1852. He would be a minister, his mother prophesized until she died in his ninth year. I see Charles, five years later, possessed. The adolescent feverishly chalks bible verse on cobble sidewalks. He leaves portents of hellfire and damnation in the men's clothing store he manages for his father. His optimism, like that of any child, is heartbreaking: he believes he knows how to save the world.

There is a game of billiards near the end of his high school term, I read. He's frustrated by his inability to reconcile the Hellfire of eternal damnation with a just, loving God. Lining up his shot, Charles asks his opponent, "Would you hold a puppy's tail in the fire for even three minutes?" The ball hits the back of the pocket. He presses further, "A loving Father would never do that to his children."

But, says his opponent, the voice of reason. In the Bible.

It is the Bible, God's word, Truth, Charles realizes, that always trumps even the best logic, the most sincere emotion, the oldest ethic. He starts a Bible study group. Over a century later, I read his recollections of the group, "The study of the Word of God with these dear brethren led step by step into greener and brighter hopes for the world." In the pages of the books I read, the names of his colleagues accumulate like empty shells: George Stetson, George Storrs, Nelson H. Barbour, Professor Fischer, Adam Clarke, Sir Isaac Newton, Dr. Joseph A. Seiss. These names hold nothing of the former selves. They do not self-promote.

The Witness I've been meeting seems to believe the opposite: his name contains him. By erasing it, he believes he's effacing himself. Sitting in the library, I recollect one of our last meetings at the coffee shop: Two of them arrive together with their briefcases and long overcoats, like a pair of Feds about to flash badges and escort me to the station. I recognize my Witness's partner from the Kingdom Hall, a tall and paunchy black man with gray sideburns and a smile that lifts his cheeks into creases beside his eyes. We shake hands. His grandfatherly grip embodies Study 33: Tactful yet Firm. He straightens his red tie, introduces himself and encourages me to shorten 
his name. He's a Syracuse grad who moved out here to get away from what he calls "East Coast arrogance" and to get a masters degree. His kids are students now. He recollects the perspective he once shared with former friends: Everyone out here in the Midwest is all the same, all corn-fed on ignorance and all dull.

"Funny," I say. "My friends out East think the same thing. I love it here." Me too. He says.

We sit together and chat round a small table. Our chairs are pushed back so we don't bump knees. The talk is trivial except that the Witness I've been meeting, the one who called three times the other morning just to check in, who always knows what chapter and verse to turn to, who is always so sure, keeps incorrectly referring to his fellow Witness as Bill.

But his name isn't Bill, I say. And we all half-laugh into the tops of our paper coffee cups.

Oh. Yes, he says, he must have been thinking of that Celtics basketball player who won all those championships. He looks up to recollect the last name.

Bill Russell, I think for sure.

Bill Walton, he says.

"Bill Walton?"

Charles was a man, I conjecture from my reading, possessed with a kind of pig-headed innocence, believing with a touching combination of naivete and conviction. He scoffed at the science of geologists and their timelines. "Of course, if we estimate [the age of the earth], just as these great men do, we should reach the same great conclusions." Bishop James Usher's King James calculations regarding the age of mankind, he concluded, had underestimated by 124 years. When Charles was not transported to heaven in at his initial predicted date of 1878, he revised. He interpreted the Greek parousia as "presence" rather than the traditional "coming," and it was common knowledge that Christ's presence, preceding Armageddon, would be felt during the seventh "day of the Lord." He knew that the first day of the Lord began after Nebuchadnezzar overthrew Israel in 607 B. C., but converting "days of the Lord" to earthly days proved tricky. Charles finished his formula by equating a Lord's day with the biblical use of the word "time." He equated 1260 earthly days with a phrase from Revelation: "a time, and times, and half a time," or three-anda-half "times." That meant seven "times," seven days of the Lord, equalled 2520 days, or exactly seven 360-day scriptural years. Accordingly, Christ would arrive for the second time in 600 B.C.- six hundred years before the first time. 
The contradiction didn't stop Charles. He deduced that Jehovah had meant each of Charles's 2520 days to equal one year. So Christ would arrive, invisible, smack in the fall of 1914. There was much to look forward to.

Congregations developed. Sitting in the straight-backed pews of a small chapel with white-washed walls, I see Charles striding and shouting and echoing off the walls. His black coat emphasizes every gesture. Charles, it's true, is a man of great charisma and zeal. After the meeting, converts chuckle, slap backs, vow to take the literature to their neighbors.

The Studies in the Scriptures open on the carrel in front of me is the 1914 edition. The pages are browning like an apple slice left out too long. As I read Charles's words, I hear the hymn we sang last week at the Kingdom Hall, Make the Truth Your Own. Charles writes:

"All these things have been hidden by the Lord, in such a manner that they could not be understood or appreciated until the due time had come.... The Truth seeker must, so far as possible, make every point, argument and proof his own."

To make the truth their own, Russell's Bible Students all read the same literature and all heard the same sermons proliferated by the same man. In addition to yearly speaking tours covering 30,000 miles across the United States, Canada, and Great Britain, Charles had columns syndicated in 4000 periodicals, reaching millions of weekly readers. By the time of his death, he had published over 50,000 printed pages. Writing at a rate of 781 pages a year for sixty-four years, the stack would rise about twelve feet. I imagine millions of towers four feet taller than the monument at his Pittsburg grave and twice his living height. With two volumes of his Studies under my arm, I carry a little of him home myself. His last words, uttered while suffering from cystitis in his private train-car, outside the little town of Pampa, Texas, on Halloween 1916, are revealing: "Wrap me in a Roman toga."

We've mapped the whole world! he exclaims, looking through the steam of another cup of coffee. Every year, he and millions of others spend more then one billion hours evangelizing. They walk quiet sidewalks. They shoulder up busy streets. They go down dead-end dirt roads. It is, he says, the greatest preaching campaign the globe has ever known. Training occurs once a week at the Kingdom Hall. I recall a lesson: How heartwarming it is to know that even a parapalegic girl in India could turn the pages of her 
Bible with her tongue and conduct the ministry over the phone. You too could have your name inscribed in Jehovah's book. The Bible in the new system of things might read: Brother so and so was a friend of God. Wow! How would you like that?

His conversion story is nothing special, he tells me. There are plenty of conversion stories in past Watchtowers I should read, he says. Witnesses, he says, do not self-promote.

According to their website, Witnesses baptize about 250,000 members a year. As congregations develop, they generally do not exceed 200 members. Brothers and Sisters checkout territories like library books and form car groups to cover the miles. Pioneering, it's called. They take inventory on a HOUSETO-HOUSE RECORD: CA - call again, $\mathrm{NH}$ - not home, B - busy, $\mathrm{C}$ - child, $\mathrm{M}$ - man, W-woman. The slips come in like corn to a September silo.

Generally, he says, it takes more than six months to be Fellowshipped. You can't just sign up. It involves lifestyle change and informed consent. A committee of Elders interviews you from a list of over one hundred questions. Jehovah, you must know, cannot be seen or known, but He knows you like He knows all of the names of the 200 billion billion stars he created. Witnesses took the name Jehovah's Witnesses in 1931, and they refer to Him as Jehovah because, he says, you would never deny your best friend his name. Nor would you hurt a friend, he says. Jehovah hates certain things: abortion, manslaughter, violence, hatred, sexual immorality, discrimination, spiritism, drunkenness, idolatry, stealing, lying, greed, improper speech. He loves you. That's why, he says, he would not sell tobacco if he owned a convenience store. He would not administer blood transfusions as a doctor, nor would he accept a transfusion. An organ transplant would be okay, but only if the kidney was first drained of blood. He would not work for a defense contractor in any capacity. He would not fight in an Earthly war. He is non-political. He does not vote. The Supreme Court has ruled that he does not have to pledge allegiance to the flag.

He removes the plastic cap from his cup of coffee. Beads of condensation cling underneath. Witnesses don't celebrate birthdays or Halloween or Easter or shake in the aisles or burn incense either, he continues. It doesn't mean they don't live joyfully, he says. They celebrate one day a year. See here in Luke 22:19.

His Bible is beautiful. The leather cover shows fond creases. He opens the book. I see his name inked in tilted script on the inside cover and then the pages are fluttering under his practiced fingers. Could he tell me a little about his Bible, I ask. 
Yes, he says, the Bible is a practical book. Is it not amazing that some forty men, writing in a number of lands over a span of 1600 years, produced this beautiful consistent book? He describes it just as Charles Taze Russell did: harmonious and accurate. The Bible, he says, is historically sound. The Bible predicted in Matthew 24:9 that Witnesses would be persecuted. The Bible reflects a keen understanding of human nature. The Bible is scientifically accurate. In his Palm Pilot, he's archived thirty years of Watchtowers and the article he references explains why a nuclear physicist believes the Bible. Witnesses remain distinct individuals, he says, but Bible study has allowed them to become happier and more balanced. The Bible, he says, contains the Truth. It says so right here in 2 Timothy $3: 16$. We know the Bible is the Truth, he says, because the Bible says it is the Truth.

I hold the Bible he gave me weeks ago in the palm of my hand. In 1950, an anonymous Committee produced the New World Translation of the Bible. It is more accessible than the King James version, without all those archaic Thees and Thous, without mention of hellfire, without a cross, without the abstraction of the Tetragrammaton. In this translation, Jehovah is mentioned by name over 9,000 times. The 1,600 cross-referenced pages are thin as tissue and square as a postcard. The black plastic cover mimics authentic leather. New World Translation of the Holy Scriptures is stamped in gold.

He removes his bifocals and inspects them. He drinks the cooling coffee with big silent gulps. The Truth, he quotes Jesus with unrelenting eyes, will set you free. See here, in Matthew 24:3, it says Jesus will be invisible. Now why would Jesus need to give us signs of his arrival if he was visible? Knowing Jesus is like knowing Truth, he tries to explain. It can depend on just the right question at just the right time.

Is it so improbable to suppose he might acknowledge himself in such a way as to reveal an identity separate from the literature? Take a moment now to marvel at how unique we all are! Look into the reflection in your coffee. Look at the man across the table. See all of that man with those small cartoonish ears and that gracious concern. In his hand, he holds a book that eliminates mystery, has seen everything, can give sight to those who have none.

One blind man exclaims the elephant is a snake, while another insists it is a wall.

After the Watchtower Study ends with hymn \# 152, he introduces me. Brother, Sister, this is Matthew. 
Are you his son? If you're writing about us, you'll have to come back to see if we've been brainwashed or if we really know the Truth. Matthew! Matthew! It's complicated: I was Catholic until I turned nineteen. The day I was supposed to meet with my pastor - I was searching for the Truth then, probably like you are today - to discuss my feelings, two witnesses came to the door. It had been raining all week. When I opened the door I saw they had brought the sun. I believe in omens. I already hated Christmas, so that was easy. It has roots in paganism, you know. I was working in a mall, and I saw people transformed into animals. Matthew! Matthew! I met my husband, a Brother, in the Phillipines. We're really very accepting here. Are you at the U? What do you think computers have done to the English language? Can you explain what you teach, I don't understand. I can never keep fiction and nonfiction straight. Which one is real? Matthew! Matthew! Did you know that all the Halls are built by volunteers? I worked in the gardens outside and helped with the concrete. I do hardwood floors. I do tile. I used to teach psychology to grad students. I'm an architectural engineer. You grew up in Maine, have you ever had lobster? I like seafood. My sister-in-law is always cooking shellfish. We've seen the Atlantic. No whale is exactly the same.

I'm a category five Hurricane, one elderly gentleman says to me. I've got six kids and the oldest is 51 . I've got fourteen grandkids. I'm 79 and my wife's 82 . Your name's Matthew? You've got a whole book dedicated to you. He hefts his beaten leather Bible to my chest. Read this, he instructs. It's John 17:3.

Three women spectate from the row in front of me. Another Brother drapes his arms across the shoulders of his two children. I keep thinking about what he said to me weeks ago in the coffee shop, about finding something he loves and wanting to share it with others. He said something else too. He said it is the gift of Truth that converts, not him, not the Witness. Remember that book you read years ago? Remember how confusing it was then, until, without warning, everything made sense? The Truth in the text silently converts, surreptitiously saves, invisibly passes into you. It makes a host of you. You carry the Truth now. You love the Truth. You see nothing but Truth.

He looks grimly over my shoulder as the verse speaks: This means everlasting life, their taking knowledge of you, the only true God, and of the one whom you sent forth, Jesus Christ.

You know the opposite's true too, don't you Matthew? If you don't put faith in Jehovah-

he chops his neck with his hand. 
The day after Christmas, I am in my parents' house in Maine and a shiny black SUV comes sliding down the isolated driveway. It's the Witnesses. My mom says she hasn't seen them in years. Refusing to believe that this house call is mere serendipity, I try to rationalize. He could have called them from Iowa City and told them to look me up. Our house might just have come up next in this territory's rotation.

I don't open the door all the way, but I open it. Snow melts from the roof in drips that darken the front step. They brought the sun, I think, creepy. There are four of them. Two men wait in the idling vehicle. One woman does most of the talking. She introduces herself and her partner. She asks me my name. She asks if I have a Bible. While she assures me that there is a creator who cares, her partner looks past, into the kitchen, as if she recognizes the warmth inside. I take a Watchtower and we chat about the weather and hometowns. I tell her I'm glad to be back with my family, listening to old audio cassette-tapes of birthdays past and eating stocking chocolates. That sounds nice, she says, but what about my post grad-school plans.

Questions like this one, that come from out of the blue and engage me and my future, are never easy. I avoid them by tricking myself into thinking I know who I am, what I want, who I will become. Though I Know How I Ought To Answer with An Effort To Reach the Heart - today, I have none.

She senses my discomfort. Moving her lips to anticipate the first syllable, she asks me my name again.

I tell her, and, still struggling to answer her first question, I mumble vague optimisms. 